\title{
NARRATIVE ASPECT OF THE "DEVIL" CONCEPT SUGGESTION IN GERMAN STUDIES OF THE 20th CENTURY (BASED ON THE NOVEL "MEPHISTO" BY K. MANN)
}

\author{
Vadym Humenyi \\ Lecturer, Petro Mohyla Black Sea National University, Ukraine \\ e-mail: identityisunclear@gmail.com, orcid.org/0000-0003-1270-8893
}

\section{Summary}

The article discusses the features of the suggestion of the concept "Devil" in German studies, examines the relationship between the sub-concepts "evil" and "sadness" in the context of the preservation of narrative structures in translation, and also revealed the main features of the concept under study. There is a statement that suggestion is a way of interpreting a certain message through a combination of logical and emotional components at the syntactic and morphological levels, which affects the consciousness of the recipient. The inculcation of religious concepts provokes certain states or feelings of a person, encouraging them to commit acts that don't correspond to the initial psycho-mental portrait of a person, awakening and deforming the reader's subconscious perception of reality.

Particular attention was paid to the study of the methods of translating the direct speech of the author from the original language to the target language, which reveal the main criteria for distinguishing between unreliable types of representation of the concept under study. During the analysis also was described a step-by-step application of the context-interpretive method of preserving narrative and was discovered the concept of "cognitive context", which has a paramount importance in the minds of native speakers, and gives an opportunity to get closer to understanding of author's suggestive influence on the average reader.

Keywords: translation, verb, context, narration, recipient.

\section{DOI: https://doi.org/10.23856/3804}

\section{Introduction}

Modern art tries to reflect the new state of the world, in which few can distinguish where the true spirituality, and where the pathetic imitation and cheap surrogate of true human feelings. In the XIX century. the image of the devil ceased to be a purely religious element, and this happened as a result of the final completion of the process of its secularization. In the XX century the devil firmly entered the circle of traditional characters in literature, cinema, music, and fine arts. This cultural phenomenon and unique image, coming out of the cradle of ancient religious ideas, is firmly entrenched in the public consciousness. Synonymous with all the negative, destructive to life, the image of the devil is widely used around the world, which makes it necessary to study the suggestiveness of religious and esoteric concepts in works of mass literature and their extrapolation to people and society as a whole. This study will provide an opportunity to track the psychological content of the author's language under the influence of socio-psychological factors, the relevance of the influence of intralinguistic factors, as well as mechanisms for its implementation in the concept at the level of narration, which is the subject of this study.

Suggestion is combined with the theory of fiction and the theory of interpretation. In this sense, it is necessary to clarify the adequacy of the transfer of mental influence of the studied 
concept "Devil" as a full-fledged interpretive mediator of the original language and author's style to the language of translation. The purpose of this study is to highlight the features of the suggestive influence of the concept "Devil" as an element of the picture of religious worldview on the material of the novel "Mephisto" with a verbalized concept within it, as well as consideration of the identified provisions on the example of the "devil" concept. The subject of the research is the language of the author of the displayed concept, the relationship of its narrative categories with the suggestive influence on the recipient/reader.

In this research were used such methods as analytical method for establishing basic values of concept suggestion, narratological analysis of language units, descriptive method used for isolation and description of text concept, as well as stylistic method for research of suggestive means of influence of research concept and comparative method for comparison of language presentation tools. the concept of "Devil" in the original text and its translations.

\section{Esoteric concepts in language and translation}

Being "stipulated", the ideas and concepts of a particular language group come into feedback with the thinking of the ethnos as a whole, directing it along a nationally determined path: as the researcher Granovska notes, "language can be likened to a kind of cognitive-ethnic vaccine, and the process of language acquisition cognitively-ethnic immunization, through which each new member of the ethnic community necessarily passes" (Granovska, 2004). With help of language signs reflects the way of worldview of the ethnos, worldview through the prism of national-cultural ideas and images, which makes the national language the most important ethnogenic factor, "the main means of "ethnic socialization" of the individual" (Arnold, 2003).

In modern linguistics recognize the main approaches to understanding the concept, which are based on the following position: concept - the result of the collision of the meaning of the word with the psychological experience of man, ie the mediator between the word and the spiritual state of the recipient.In addition to the types of concepts that are mental formations of hyperonymic order, there are also their hyponymic varieties - classes and subclasses of concepts, distinguished by the cognitive-semantic principle.

The suggestion, as the researcher Raigorodsky points out, should be distinguished by the content and the result of the impact:

- positive (ethical) suggestion - manipulation of the consciousness of the individual, group in order to improve their socio-psychological condition.

- negative (unethical) suggestion - irresponsible manipulation of the consciousness of the individual, group.

And also in the form of implementation:

- heterosuggestion - the effect of the suggestion on the suggestive from the outside;

- autosuggestion (self-suggestion) - conscious self-regulation, suggestion of certain ideas, feelings, emotions, and "with such a suggestion, the suggestor and the narrator are the same person" (Raigorodsky, 2001).

As Suprun rightly points out, the concepts of moral order are close to theosophical, but in contrast they are regulatory, because they "not only reflect the general ideas of mankind about moral values (good, evil, sin, untruth, honor), but also offer norms of behavior in the world and society: truth, longing, good, good and evil" (Suprun, 2014). At the same time, they set the general outline of such behavior, as a result of which each person is given the right to have his own idea of these values, accepting or not accepting them as a standard, but often with individually different associative imagery. 
The influence of the concept through the narrative is due to the intimacy of the communicative space. Its purpose is to create an atmosphere of trust and friendliness, because suggestion is impossible without trust in the addressee and researcher Ilnytska also concludes, that "the formation of trust in the addressee is realized in a suggestive form with the help of certain methods of aggressive imposition of the necessary information" (Ilnytska, 2006).

Making a "pure slice" of these concepts, we can conclude that each native speaker, implementing a concept, contributes to its objective content elements of subjective experience, which most often affects the religious and esoteric layer of literary concepts, namely - the concepts of "God and the Devil". There were identified two main terms:

- Over the centuries, humanity has formed the concept of the devil, the first clearly organized and constructed module of which appeared in the New Testament. In the Middle Ages, the New Testament devil acquires additional characteristics and new meanings. Christian demonology carefully shapes, cultivates and in every way equips the image of the devil with innumerable negative characteristics. This process continues today. At the same time, in culture, the image of the devil is reflected in its specific, aesthetic and artistic features and their interpretation.

- In the history of culture - both in religious consciousness and in the field of art - the image of the devil often acted as a semantic core, as a symbol of global scourge. Changing sometimes in partial manifestations, this aspect of concept became a general cultural category, encompassing philosophy, and the sphere of morality, and religion, and art, and the sphere of everyday life.

\section{3. "Devil"' in "Mephisto"}

Religious-philosophical and cultural-historical idea of the devil is, like the concept of God, a phenomenon that develops and has a serious suggestive effect on the mentality of people, which can cause irreversible social consequences and total spiritual catastrophe in our life. The psychotype of the devil-artist matured in the aesthetics of K. Mann as the embodiment of the idea of synthesis of arts, which provided a way to a single world, its transformation and renewal.

In K. Mann's novel Mephisto, against the background of the hero's immersion and "calmness," the problem of the unification and renewal of fragmented Germany arises in all its urgency, contributing to the explosion of revolutionary sentiments in 1848-1849.

In this regard, the idea of the synthesis of arts and the appeal of K. Mann to the image of the devil-artist were, in a sense, an appeal to the aesthetics of romantic universalism. In the image of the devil, the artist stated that he went beyond the empirical reality - "aesthetic man", which replaced the "utilitarian man". According to K. Mann, "A man-artist embodies his essence, uniting all his creative abilities and all art forms. In his work he asserts himself in the fullness of his being as a whole." The "artistic devil" is a strong, beautiful man who has risen to the heights of free human dignity, embodying the world's hopes of true humanity. To him belongs the whole world as an eternal, inexhaustible source of the highest pleasures.

The peculiarity of this concept is that speakers of a certain culture and a certain language are associated with such background knowledge and associations, which at a certain stage of interethnic and interlingual contacts may be absent in speakers of other cultures and languages.

In the image of the devil, K. Mann's intention to ontologize artistic reality was guessed. Slyvka notes that "K. Mann sought to abolish the differentiation between art and life in order to transform man and the world. Synthetic art acts as an environment for the global synthesis 
of all phenomena of life, the creation of a certain integral style of culture, in which "aesthetic sacrament" should become the focus of spiritual self-expression of the people and the individual." (Slyvka, 2008). Representing the type of the devil-artist as the embodiment of the "manifestation of the inventive spirit", K. Mann intuitively connected the aesthetics of artistry with the Faustian aesthetics.

For this research, it is important to understand the frame of the researcher Golubovska. "Knowledge structures, called frames, schemes, scenarios, plans, etc., are information packages that provide adequate cognitive processing of standard situations." (Golubovska, 2004). It is also correct to think that a frame in frame semantics is at the same time: a) a set of assumptions about constructing a formal language to reflect knowledge as an alternative to semantic grids or to calculate predicates; b) a set of entities, according to the researcher, which exist in the depicted world (metaphysical interpretation of the concept) (Golubovska, 2004). The frame gives an idea of what kind of knowledge is essential for such a description, which is the organization of ideas stored in memory (human and / or computer), and the organization of processing and logical inference that operate in this area (heuristic, or implementation, interpretation).

The study of concepts embodied in an artistic text involves the study not only of the conceptual component formed by the set of its usual invariant features that form the core of the concept, but also the addition of occasional (peripheral) features that are manifested in speech. One of the ways of presenting concepts in cognitive linguistics is considered to be frames, the typology of which was carried out by us on the basis of the analysis of language material, as a result of which seven thematic groups were singled out. This is confirmed by the texts in which the studied concept finds its linguistic realization, for example:

Als dieser hohe Geist, jenes Morgenstern des Bösen, vom Himmel fiel, war es wie ein Rebell, dass er fiel (Klaus Mann, 1936).

In this fragment of "Mephisto", we identify the concept of "Devil" due to the key component Morgenstern des Bösen (Morning star of evil), which, given the etymological facts and culturological data, paraphrastically nominates Lucifer: (aus Lateinische Lücifer) - Lichtbringer (the one who carries light), actualizing the attributive aspect of the concept within the first frame "the devil as a negative mystical supernatural being" and positioning the latter as lost (hohe Geist), ost angel, leader of rebellious comrades:

Den Erzengel aus dem Himmel geworfen, um den Aufstand der Engel zu führen, which is confirmed by another lexical marker vom Himmel fiel, which implies the gnostic vertical as a vector that connects two worlds: the world of the sublime - the spiritual and the world of the low - the sinful, metaphorically defining the direction of movement from top to bottom as an act of moral fall. In this regard, we have a basis for the reconstruction of the conceptual scheme of the devil - a fallen creature.

\section{Frame deconstruction of "Mephisto's" Devil}

In this fragment of the novel by K. Man, the image of Hendrik Hefgen stands by the devil's eyes, as a hiring representative of the mystical unreal light, as a creature, which will give the beggar superpower to his comrades:

Ich habe mehr Stürme als der Wind, denn ich diene dem, der stärker ist als der Wind, und mit einem Sieb und einem Eimer Wasser kann ich die großen Galeeren auf den Grund des Meere schicken (Klaus Mann, 1936).

In the middle of another frame, "the devil is a devil, which induces to negative ideas", the concept is actualized in contexts, the referent is presented in an emphatic way, to the criminal 
and immoral actions, so it demonstrates the soulfulness of master: Und als der junge Mephisto diese Worte hörte, zitterte er und sprach zu seiner Seele: "Nein, aber du bist böse und hast mich meine Liebe vergessen lassen und mich mit Versuchungen versucht und hast meine Füße in die Wege der Sünde gesetzt” (Klaus Mann, 1936).

The concept of evil is identified in this context through its linguistic nominators böse (evil, wicked), versuchen (seduce) and hast meine Füße in die Wege der Sünde gesetzt (instruct on the sinful path), which, while retaining the negative axiological component of meaning, have a counter-suggestive effect on the recipient reader.

The development of the concept within the third frame "the devil as an object of serving", which regulates the probability of feedback of earthlings with evil mystical forces to conquer the latter, can be illustrated in the following fragment, which depicts the mystical interaction of dark forces with real earthly creatures:

Hendrick ging mit einem Schmerz in seinem Gesicht zur Tür. Als er den Vorhang zur Seite zog, brach ein scheußliches Lachen aus den bemalten Lippen der Frau, die sein Geld genommen hatte. "Da geht der Teufel!" Rief sie mit heiserer Stimme (Klaus Mann, 1936).

The concept of "devil" in this fragment is identified by its explicit verbalization as part of the key element der Teufel (agreement with the devil) and implicit text markers (terrible laughter) and ein scheußliches Lachen (hoarse voice), which, despite their immediate and Frau traditionally denote characteristics that are mostly characteristic of men or other rude, evil, indomitable creatures, which leads the reader to think of the existence in the form of a masculine woman of a veiled mediation by the devil himself, or of Satan's involvement as a woman. one of his antics - to search for verbal contact, carried out only in the presence of the articulatory apparatus, and hence the physical form. In this case, the devil speaks through the mouth of the sinister heroine. The subject of the action is Hendrik Höfgen, and the devil himself is the initiator and at the same time the beneficiary of the concluded agreement. Such reflections are confirmed in another context, where the devil is also the main protagonist for whom immoral acts are committed:

Schlagen Sie mich dumm, wenn es nicht so. Er [Mephisto] ist der schlechteste, der hier kommt. Sie sagen, er hat sich dem Teufel für ein hübsches Gesicht verkauft (Klaus Mann, 1936).

The lexeme-nominative Teufel in the key element er hat sich dem Teufel für ein hübsches Gesicht verkauft to denote the referent as the recipient of an action directed at him by another subject of speech (Mephistopheles), actualizes the actional aspect of the concept that reveals the devil to the devil as the object of a trade agreement concluded in his own favor to corrupt a person and his loss of moral guidance in exchange for a dubious or ephemeral reward (Askoldov-Alekseev, 1997) in this context - ein hübsches Gesicht, while the subject of the agreement acts as the trader of his own personality, as evidenced by the verb verkaufen (to sell) in the specified thematic fragment. Such actions are condemned in society, which is confirmed by the presence of negative value characteristics of the protagonist of the work by other characters (Er [Mephisto] ist der schlechteste), verbalized by the adjective schlecht in the highest degree - schlechteste. Extrapolating to the reference situation that, having purchased a thing, the buyer becomes its owner, we can reconstruct the conceptual scheme of the devil is the buyer and owner of sinful souls.

Within the fourth frame "the form of the devil" the concept is actualized as a result of its explicit textual development, which can be demonstrated by a fragment where the anthropomorphic form of the referent is objectified:

Es war ein Mann in einem Anzug aus schwarzem Samt gekleidet, in spanischer Mode geschnitten. Sein Gesicht war seltsam blass, aber seine Lippen waren wie eine stolze rote 
Blume. Er schien müde zu sein, und lehnte sich mit dem Knauf seines Dolches aufs Spiel. Auf dem Gras neben ihm lag ein gefiederter Hut, und ein Paar von Reithandschuhen, die mit vergoldetem Spitze waren, und genäht mit den Samenperlen, die in ein neugieriges Gerät geschmiedet wurden. Ein kurzer, mit Sables gefüllter Mantel hing an seiner Schulter, und seine zarten weißen Hände waren mit Ringen beschmiert. Schwere Augenlider hingen über seine Augen. Der junge Arzt beobachtete ihn, wie man in einem Bann zerbricht (Klaus Mann, 1936).

Undisputed in this context is the abstract form of the devil as the lord of darkness, verbalized by the nominative ein Mann in einem Anzug aus schwarzem Samt gekleidet, which appears in English ideas as a male person (Mann) and is closely associated, first, with color symbolism - black (schwarz) as the color of darkness and sin, signifying sorrow, grief, loss / loss or death, and red (rot), the color of Satan and hellfire in Christian symbolism, which often implies a thirst for blood and revenge, or strength, power and courage; secondly, the devil is associated with wealth, which is confirmed by the presence of descriptive context elements such as Hände waren mit Ringen beschmiert (hands decorated with rings), gefiederter Hut (hat with feathers), vergoldete Spitze (gold lace / ribbon), Samenperlen, ein kurzer, mit Sables gefüllter Mantel (cloak on sable fur), etc., which are traditionally considered attributes of well-being and prosperity. The militancy of the devil is symbolically represented in the text in the form of a dagger (Dolch), which metaphorically denotes his bloodthirstiness and mystical ability to kill, destroy or ruin both the physical and spiritual essence of man - in which we see the realization in language of the semantic sign "Zerstörung").

During the analysis, were become of several suggestive schemes:

devil is sorrow, destruction, or death;

devil is militancy;

devil is wealth.

Otherworldly forces, including the devil, sorcerers, ghosts, etc., and related phenomena (suggestors), as a result of ingrained prejudices in society, usually make utilization suggestions, which, as the researcher Goncharov "rightly points out, can naturally be uncritically perceived by a person, they are sincerely admired" (Goncharov, 1995), and cause fear of the person who comes into direct contact with them, with their manifestations in earthly life or even hints at their existence, for example:

Während ich mich sanft aufsetzte, schlug mir das letzte Geräusch, das ich erwartet hatte, in so einer Region zu lachen, ein Lachen. Es war ein merkwürdiges Lachen. Das Lachen war so tragisch, wie vornatürlich ein Lachen, wie ich es je gehört habe; Und daß es ein hoher Mittag war, und daß kein Umstand der Geisterhaftigkeit die merkwürdige Cachinnation begleitete; Aber daß weder die Szene noch die Jahreszeit die Furcht begünstigte, so hätte ich fürchten sollen (Klaus Mann, 1936).

The concept under study is identified in context by the key element Geisterhaftigkeit, which nominates the probability of the presence of unreal etheric beings - spirits (which includes the devil himself as their leader), whose earthly period in Victorian notions is limited to dark time Hochmittag (noon), which is with a key element in the causal relationship, marking a precedent and preventing the very presence of any ghostly creatures at noon. The semantic relay of the concept and its integral feature in this case is the fear (Furcht), which, according to the context, should be felt by the participant of the situation who faces a similar phenomenon (so hätte ich fürchten sollen). Thus, by explicating the concept of the devil on the basis of the oppositional relations between the elements of the dismembered chronotope day - night, we are able to reconstruct the conceptual schemes: the devil is the night; the devil is fear. 


\section{Conclusions}

In this research was identified realization of the concept "devil" in the Klaus Mann's novel "Mephisto". On the basis of the inventoried thematic fragments were investigated its variant signs and established basic conceptual schemes. As a result of the analysis, it was proved that the development of the suggestion of the text concept "Devil" takes place within four main separate thematic frames, which highlight the ontology of being a referent and reveal the usual and occasional features of the "devil".concept

After the analysis, it can also be noted that the image of the devil-artist in K. Mann's novel "Mephisto" appears as a direct or indirect multiplier of evil, which also allows for the reconstruction of the conceptual scheme of the devil is an amplifier (multiplier) of evil.

Thus, the study shows that the concept of "devil", in the context of suggestion, contains spiritual and abstract concepts that are destructive for human nature and its spiritual balance. The concept of "Devil" takes an important place in the image of the world art, along with such concepts as God, Love, etc. Consequently, it is of great importance for understanding the verbal picture of the world that exists in the minds of native speakers, allows us to immerse into subsequent researches with goal get closer to understanding the cultural heritage of the mankind.

\section{References}

Arnold I.V. (2003) Sty 'listy 'ka suchasnoyi nimecz koyi movy [Stylistics of modern German language]. Kiev: Zirka [in Ukrainian]

Askoldov-Alekseev S.A. (1997). Koncept ta slovo [Concept and the word]. Moskva: Academia [in Ukrainian]

Golubovska I.O. (2004). Etnichni osobly vosti movny`x karty'n svitu [Ethnic Peculiarities of World's Linguistic Paintings]. Kiev: Logos [in Ukrainian]

Goncharov G. A. (1995). Suggesty ya: teoriya ta prakty'ka [Sugesty: theory and practice]. Mariupol': KSP [in Ukrainian]

Granovska R.M. (2004). Psy xologiya viry`[Psychology of Faith] SPb.: Publishing House "Rech" [in Ukrainian]

Ilnytska L. L. (2006). Anglomovny j sugesty `vny j dy skurs [English-language suggestive discourse]. Kharkiv: Svit. [in Ukrainian]

Klaus M. (1936). Mephisto. Roman einer Karriere. [in German]

Raigorodsky D. A. (2001). "Zakvaska” naviyuvannya. "Psy'xologiya ta psy xoanaliz xarakteru" ["Sour" of sugesty. "Psychology and psychoanalysis of nature"]. [Electronic resource] // Access mode: https://bookap.info/psyanaliz/raygorodskiy_psihologiya_i_psihoanaliz_haraktera/gl113.shtm Lviv [in Ukrainian]

Slyvka N.T. (2008). Leksy 'chno vy 'razheny j koncept z tochky zoru kognity 'vnoyi semanty 'ky' [Lexically expressed concept from the point of view of cognitive semantics]. Uzhgorod: Modern Studies in Foreign Philology. [in Ukrainian]

Suprun V.M. (2014). Ponyattya "koncept" u terminologichnij sy stemi filologichnoyi nauky" [The definition of "concept" in the terminology system of philological science]. Kiev: State and regions [in Ukrainian] 